This is an electronic reprint of the original article. This reprint may differ from the original in pagination and typographic detail.

Author(s): Ruohotie-Lyhty, Maria; Korppi, Aino; Moate, Josephine; Nyman, Tarja

Title: $\quad$ Seeking Understanding of Foreign Language Teachers' Shifting Emotions in Relation to Pupils

Year: $\quad 2018$

Version:

Please cite the original version:

Ruohotie-Lyhty, M., Korppi, A., Moate, J., \& Nyman, T. (2018). Seeking Understanding of Foreign Language Teachers' Shifting Emotions in Relation to Pupils. Scandinavian Journal of Educational Research, 62(2), 272-286.

https://doi.org/10.1080/00313831.2016.1258659

All material supplied via JYX is protected by copyright and other intellectual property rights, and duplication or sale of all or part of any of the repository collections is not permitted, except that material may be duplicated by you for your research use or educational purposes in electronic or print form. You must obtain permission for any other use. Electronic or print copies may not be offered, whether for sale or otherwise to anyone who is not an authorised user. 
Maria Ruohotie-Lyhty

PO Box 35

FI-40014 University of Jyväskylä

Department of Teacher Education

Telephone: 358408012834

Email: maria.ruohotie-lyhty@jyu.fi

Aino Korppi

Liesharjunkatu 2 D 29

53850 Lappeenranta

Telephone: 358407583504

Email: aino.a.korppi@gmail.com

Josephine Moate

PO Box 35

FI-40014 University of Jyväskylä

Department of Teacher Education

Telephone: 358408053350

Email: josephine.moate@jyu.fi

Tarja Nyman*

PO Box 35

FI-40014 University of Jyväskylä

Department of Teacher Education

Telephone: 358408012869

Email: tarja.a.nyman@jyu.fi

Maria Ruohotie-Lyhty and Josephine Moate are currently post-doctoral researchers at the University of Jyväskylä.

Aino Korppi works as an English teacher in a primary school in the city of Lappeenranta.

Dr. Tarja Nyman is a lecturer at the University of Jyväskylä.

*corresponding author 


\section{Seeking understanding of foreign language teachers' shifting emotions in relation to pupils}

Teaching is recognised as an emotional practice. Studies have highlighted the importance of teachers' emotional literacy in the development of pupils' emotional skills, the central position of emotions in teachers' ways of knowing and in their professional development. This longitudinal study draws on a dialogic understanding of emotion to present findings from qualitative interviews with teachers. This study aims to provide further understanding in this area by offering a perspective into seven foreign language teachers' emotions in relation to their pupils during their first decade in the profession. The most important finding was that negative emotions decreased while the positive emotions increased. Understanding what emotions teachers face and how they deal with them may help practicing teachers better understand their daily work and support student teacher preparation.

Keywords: teacher education, teaching experience, teacher-pupil-relation, emotions, teacher development

\section{Introduction}

Teaching is by nature social, a practice that seeks to share knowledge by investing in the being and becoming of others (van Manen, 1991). As such, teaching is deeply personal (Day et al., 2006; Sutton \& Wheatley, 2003), a form of presence, '... an evolving entity, continuously constructed and reconstructed in relationship to the contexts, experiences and people with which the self lives and functions...' (Rodgers \& Raider-Roth 2006, p. 271). This relational way of being is sensitive to contextual change (Gao, 2008; Troman, Jeffrey, \& Raggi, 2007) and institutional demands (Carter \& Doyle, 1996; Schutz, 2014), and is characterized by emotional geographies (Hargreaves, 2001). Recent research indicates that emotion has an impact on instructional behaviour, engagement in school, student outcomes and teachers' well-being and job satisfaction (Keller et al., 2014). Some studies on language teacher identities even suggest that teacher development as a process is primarily emotionally driven rather than connected to changes in teachers' theoretical understanding (Galman, 2009; Golombek \& Johnson, 2009; Ruohotie-Lyhty, 2016). Day and $\mathrm{Gu}$ (2010, p. 38) bluntly point out that ignoring the 
contribution of teachers' sense of emotional wellbeing to their capacities to teach to their best is foolish' yet it is important to recognise the emotional dimension of teaching 'critically and not sentimentally or self-indulgently' (Hargreaves, 2000, p. 813). In this study, we seek to better understand the presence and role of emotion in teachers' relationships with pupils.

Emotion is a complex phenomenon involving coordinated psychological processes with affective, cognitive, psychological, motivational, and expressive aspects (Schuman \& Scherer, 2014; Newberry, 2013). Neville (2013) refers to Damasio (2003) in defining emotion as the reaction of our body to something in the world around us. Distinctions have also been drawn between 'emotion' and 'feeling'. Zembylas (2003, p. 233), for example, defines emotion as something objectively detectable and quantifiable in our bodies and feeling as the subjective experience of emotion (Neville, 2013, p. 4). Sullivan (2007) notes that feeling is a spontaneous reaction within a particular moment, whereas emotion is part of a sensing self acting in relation to others (Sullivan, 2007, p.108), bestowing 'a form and a value upon others' (Sullivan, 2007, p. 110). These different conceptualisations suggest that emotion is a medium through which people relate to, make sense of and use to act in the world and as Hargreaves observes for teachers 'emotion, cognition and action, in fact, are integrally connected' (ibid., 2000, p. 812). Campos, et al. (2011) explain that emotion registers an event as important and indicates that a person is ready to act, "to establish, maintain, change, or terminate the relation between the self and the environment on those matters that are important" (ibid. 2011, p. 27). In this study we understand emotion to signify the importance of a relationship for teachers, as well as an indicator of the way in which teachers make sense of and orient to teacher-pupil relationships.

\section{Conceptualising emotions in teaching}

Early studies in language teaching framed emotion as a psychological and individual phenomenon (Arnold, 1999). This approach drew on cognitive conceptualisations of emotion (Benesch, 2012) with emotion characterized by an assumed interiority. More recently emotion has been viewed as a relational and sociocultural phenomenon realised within a specific social and historic context (Campos et al., 2011; Zembylas, 2003) with evaluative, interpersonal and political aspects (Zembylas, 2004, 2007). School environments, for example, have been found to favour positive emotion (Liljestrom, Roulston, \& deMarrais, 2007). Nevertheless, during the school day all teachers encounter different kinds of educational challenges stirring 
different emotions (Golby, 1996), especially as the teacher role expands to encompass pastoral, social and psychological responsibilities (Kauppinen, 2010).

Research suggests that the more teachers' inner emotions are consistent with their expressed emotions, the more satisfied they are with their work (Zhang \& Zhu, 2008). Although this finding underlines the importance of teachers' ability to work with emotion, emotional work itself can be a source of burnout, depression, exhaustion and disappointment with work (Hagenauer, Hascher, \& Volet, 2015; Wharton, 2009). This contradiction highlights the need for a better understanding of teacher emotion. It is already recognised, however, that pupils are a major source of positive as well as negative emotion for teachers (Hargreaves, 1998; Cowie, 2011; Xu, 2013). New teachers, for example, may have idealised notions regarding pupils, teaching and pedagogic relationships (Ruohotie-Lyhty, 2013) or insufficient pedagogic repertoires to address challenging classroom situations (Kumazawa, 2013). Encountering these discrepancies can be an emotionally difficult experience (Sabar, 2004). Given the importance of emotion in teacher development, our interest is in what kind of emotion is present in teacherpupil relationships and whether teacher emotion can act as a signpost to help teachers reconsider their understanding of their pupils, pedagogic responsibilities and experiences. Rather than viewing negative emotion, for example, as something intrinsically bad, we aim to explore whether different emotions can constructively contribute to teacher development.

In this paper we use a narrative approach to study emotion as this recognises the personal and relational aspects of emotion as well as the sense-making and orienting role of emotion (Aragão, 2011). Conceptualising emotion as personal and relational anticipates that researchers are sensitive to participants' subjectivity in the collection and analysis of the data, as well as in the presentation of the findings (Hicks, 1996; Sullivan \& McCarthy, 2005). Recognising subjectivity requires research to provide a space for the emotion-laden experience of teachers without assuming that an emotional response determines a particular developmental trajectory (Bakhtin, 1990; Sullivan, 2007). The challenge for researchers is to be sensitive to the personal experience, aware of the relational context and the dynamic nature of experience as the teacher participants seek to make sense of their experiences in an interview situation. By studying FL teacher emotions longitudinally, this study aims to provide an important contribution to the existing understanding of the emotional dimension of teaching. The research questions this study seeks to answer are: 
(1) What emotions are present in Finnish foreign language teachers' accounts in relation to pupils?

(2) How do emotions in relation to pupils change as foreign language teachers gain experience?

(3) What kinds of relationships frame teacher emotion?

\section{Research method}

\section{The Finnish context of the study}

In Finland teachers' educational and teaching objectives are embodied in the National Core Curriculum for basic education (FNBE, 2014). The curriculum provides the guidelines for the work of teachers and outlines the cognitive, social and cultural competencies, capacities and identity that pupils should develop through their education. Foreign and second language education are well-established features of the Finnish core curriculum with the majority of pupils starting with their first foreign language in grade 3 . The first foreign language is most often English although in recent years initiatives have been taken to increase the range of languages on offer. All pupils are required to study the second national language with most Finnish-speaking pupils studying Swedish from grade 7 onwards - although under the new curriculum pupils will begin studying Swedish in grade 6 (FNBE, 2014).

Although no nationally regulated frameworks exist for teacher education, teachers in Finland are required to hold a Master's degree that includes subject and pedagogical studies. Pedagogical studies include a number of educational courses emphasizing dialogical and reflective learning, as well as school-based practice periods. The teaching practice for foreign language teachers includes 20 ECTS (European Credit Transfer System) points of the total 60 ECTS points in education required for the language teacher qualification. In foreign language teacher education, student teachers are particularly encouraged to focus on the development of pupils' cultural, metacognitive and communicative skills.

\section{Stages and participants of the study}

This study of foreign language teacher emotion is part of a longitudinal research project investigating newly qualified FL teachers and their development. The first phase of the project began in 2004 with 11 teachers who agreed to participate in the study. Over the following three 
to four years the teachers wrote essays and were interviewed 2-4 times. Studies drawing on this early data focused on pedagogical thinking, agency and professional development (RuohotieLyhty, 2009; Ruohotie-Lyhty, 2011). During the first years at work the newly qualified teachers' emotions in relation to pupils were predominantly negative (Nyman \& Ruohotie-Lyhty, 2008). After a ten-year period the participants were contacted again and asked to participate in followup interviews about their career and development as teachers. Seven teachers volunteered and were interviewed again in the spring 2014.

The participants of this study majored in different foreign languages (English, Swedish, German and Russian) and conducted their pedagogic studies at the University of Jyväskylä during the academic year 2002-2003. The participants were all female and about 25 years old when they started working as full-time teachers. Once their studies were complete, they mainly worked in basic education or in secondary schools in different parts of Finland.

\section{Data collection}

The data of this study comes from the semi-structured interviews conducted during the initial and follow-up phases of this longitudinal project. The average duration of the interviews was 1-1.5 hours and the language used was the participants' mother tongue, Finnish. Two of the interviewers have been involved in the project since the beginning (Nyman and Ruohotie-Lyhty) which contributed in creating an open, trusting context for the interviews. The third interviewer participated in the study as a Master's student (Korppi). Each interview was transcribed verbatim. The participants gave written consent at the beginning of the project allowing their

answers to be used for research purposes. The names and identifying references in the participants' quotations have been changed in order to protect their anonymity. One of the seven interviews in the follow-up phase failed to record due to a technical malfunction. The three interviewers, therefore, made notes immediately after the interview and combined the reports. In the findings section the interviews are numbered according to their order. During the first four years at work each participant was interviewed once a year. The follow-up interview in 2014 is marked as the $5^{\text {th }}$ interview in the results section.

The in-depth interviews asked questions regarding everyday life at work including themes such as teacher-student relationships and the participants' ideas of teaching foreign languages, however, the sequence of questions and question forms remained open to encourage 
the interviewees to raise themes that were important to them (Kvale \& Brinkmann, 2009). Although the interviewers never asked direct questions about the emotions of the teacherparticipants even the orienting questions such as, "How are you?" or "How have these first months been?" received emotional responses. When revisiting the data it is possible to say that emotion has been strongly present in each of the interviews and can perhaps be understood as an indication of the candid way in which the teacher participants shared their experiences with the researchers.

\section{Analytic approach}

Along with others, we recognise methodologies that approach teaching and emotions as rational activity are inadequate when seeking understanding of subjectivity (cf. Campos et al., 2011) and the experience of teachers (Roth, 2002). On this basis, a dialogical approach to qualitative analysis was selected as this supports the exploration of complex and conscious subjectivity (Sullivan, 2012, p. 43). Subjectivity is complex as it relates to the social as well as the personal, drawing from a network of history, tradition and power as well as from personal experiences (Sullivan, 2012). Expression of emotion can be viewed as a personal response to everyday encounters that draw from larger social practices. Emotion is not restricted, however, to a present moment but emotion can retrospectively connect with what has been as well as anticipating what might be. This broad temporal frame of emotion draws attention to the complexity of concrete, lived experience in relation to abstract knowledge (Bakhtin, 1993).

The specific tool used in this analysis consists of a narrative technique, inspired by Bakhtin, which puts different participants' experiences into dialogue with each other. This approach consists of a number of steps and involves reducing the data by identifying key moments or 'utterances of importance' in the data (Madill \& Sullivan, 2010; Sullivan, 2012). This approach, however, 'does not assume that emotions and experience are lying in the content of the text, waiting to be uncovered...' (Sullivan, 2012, p. 64). In this study, key moments were utterances in which teachers expressed a significant emotion in relation to pupils. The most obvious cases in which emotion was present were those in which the teachers explicitly referred to emotion, 'They were strange emotions - that I could hate a student'(1). In most cases, however, emotion was expressed less explicitly, yet was present in the use of adjectives or other emotionally-loaded words, 'The ninth grade left and I sighed with relief; we're getting rid of the 
bastards' (5). As the expression of emotion is a highly personal matter, the range and intensity of the words used varied between participants from the strong expressive words often used by Anu (see Appendix) to more subtle expressions from other teachers. The fact that each teacher was interviewed several times helped the researchers to become familiar with the individual ways of expression.

To form a comprehensive view of the teachers' emotional landscapes in relation to pupils and to capture the more subtle ways of expressing emotion, we drew on the dialogic definition of emotions as part of the 'feltness' of relationships (Sullivan \& McCarthy, 2004). Instead of only concentrating on particular words as indicators of emotions, we interpreted sentences in which the quality of the relationship was obvious as an emotional expression. Expressions such as, 'I think I can connect with the students rather well' (1) and 'Somehow students demand a lot from the teacher. Almost as if the teacher is their servant' (1) were also considered to be emotional utterances although the emotional aspect is only implicitly present. In these cases, defining the emotion as a negative or a positive can be problematic. To make this distinction we again relied on our definition of emotion. If the expression indicated the quality of the relationship, it was interpreted as an emotional one. Emotion that supported the teachers' wellbeing at work and made their relationship with their pupils meaningful were interpreted as positive whereas emotion that put a strain on the teacher-pupil relationship was interpreted as negative.

The first step of the analysis involved carefully reading through the interviews one teacher at a time and marking each reference to teacher emotion in relation to pupils. In the second step the most informative references selected as 'sound bites' were translated into English trying to capture the tone in the originals although hesitations and filler words were omitted. The third step involved arranging each teacher's sound bites into an imaginary dialogue between the key moments of the 'novice teacher' and the 'current teacher'. The key moments were not edited to answer each other, but placed next to one another as responses to the same 'question' (Sullivan, 2012, p. 74). Arranging the sound bites in this way brought the earlier conceptualizations, thoughts and emotions of the teachers into dialogue with their own current ideas providing intrapersonal dialogues. An example of an intrapersonal dialogue (Anu) is presented in Appendix. The bracketed number following the quotation indicates which interview the key moment came from. 
Step 4 involved re-reading each of the individual teacher dialogues and identifying commonalities between the dialogues that is across the different individual dialogues. Through this process five broader themes were identified: negative emotion, mixed emotion, positive emotion, change in emotion and changing dialogue. In Step 5 the instances of negative, positive and mixed emotion were counted and tabulated in order to gain an overview of how often they were expressed in the different career phases (interviews 1 and 2 during the first four years at work, interview 5 during follow-up, Figure1). Step 6 involved the formation of thematic, interpersonal dialogues. The most descriptive sound bites were selected from each participant and arranged as a dialogue under a particular theme. These dialogues are presented in the findings below. The sound bites were slightly edited to create fluent dialogues, however, it was of the utmost importance to maintain the meaning of the sound bite as preserved in the original interview. Arranging the data in this way created the sense of a dialogue between the participants and although this is only an imitation of a real dialogue the voices in the dialogues are quotes from the original interviews. This approach to the data analysis brings the researchers' understanding of the phenomenon as well as the interpretative nature of research to the fore (Sullivan, 2012). As Polkinghorne (1996) states, the narrative coherence is not something given, but something that is created by the researcher. By reporting our analysis in the dialogues, we bring these teachers in dialogue with ourselves and also with the readers.

Although authors one, two and four were involved in the data collection, the initial analysis was performed by the second author (Korppi) as a Master's thesis study. Once the initial analysis was complete, the identified choices were discussed within the wider research team as well as how to maintain the integrity of the original teacher statements as they were arranged into dialogues. To further support the integrity of the analyses the findings from this study were compared with previous analyses conducted on the same data set (Nyman and Ruohotie-Lyhty 2008; Ruohotie-Lyhty, 2016).

Working through these steps helps the researcher to construct the bigger picture around teacher emotion without losing the individual experiences of different participants. Furthermore, arranging the data into intra- as well as interpersonal dialogues brought the changes in the emotions and the varying emotions of the teacher participants more readily to the fore. 


\section{Findings}

A total of 120 instances in which teachers narrated their emotion in relation to pupils were identified in the data. These instances included a variety of negative, mixed and positive emotions. Figure 1 depicts the range of instances in Interview 1, Interview 2 and Interview 5 in effect illustrating the presence of emotions in different phases of the teachers' careers.

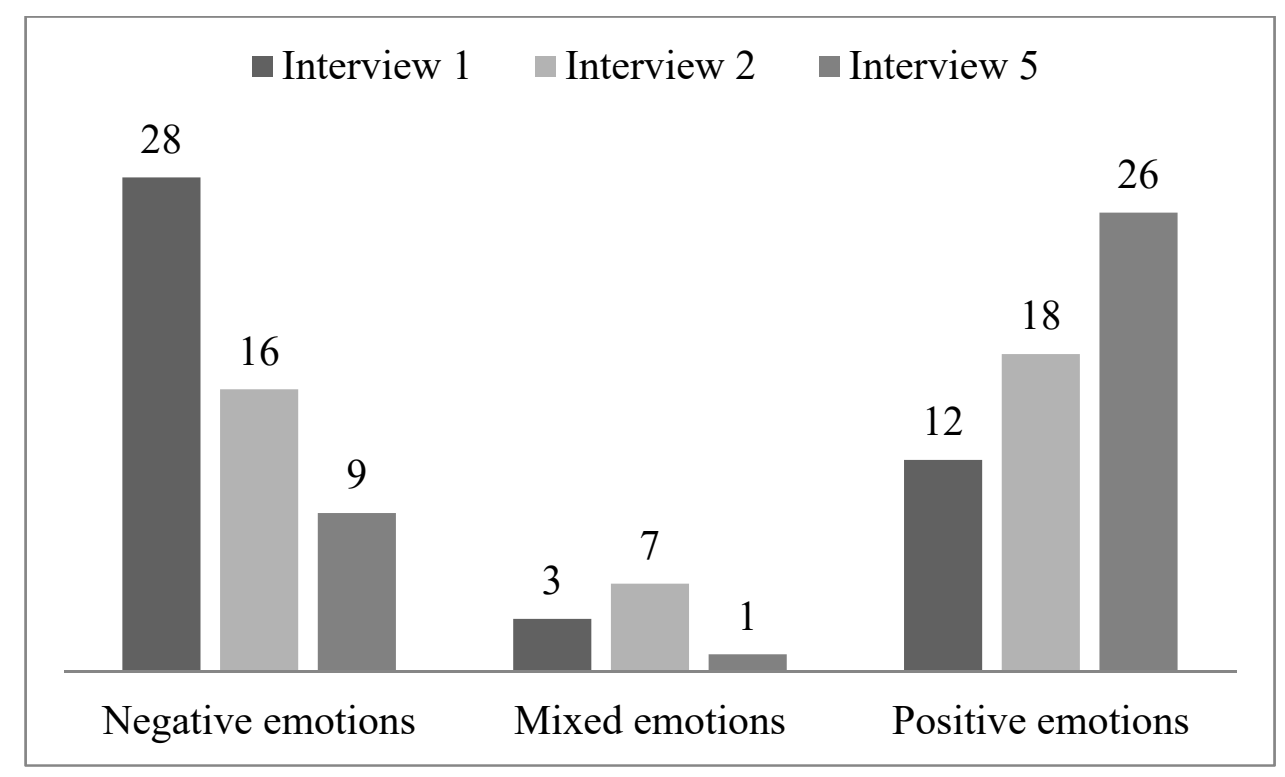

Figure 1. Instances of positive, mixed and negative emotions in interviews 1, 2 and 5

As the figure illustrates, there is a steady decline in the number of negative emotions mentioned, whereas mentions of positive emotions increased. Mixed emotions were talked about mostly in the second interview. In order to better understand the nature of emotion, each of the different types of emotion are introduced with the help of the dialogues between participants. There is an introduction before and a further analysis after each dialogue. The number in brackets after each line represents the interview: whether the sound bite is taken from the first (1), second (2), third (3), fourth (4) or follow-up (5) interview. After exploring the nature of these emotions, we will analyse the change that takes place in the emotion and the ways in which teachers deal with emotion in different phases of their careers. 


\section{Negative emotions}

Negative emotions related to pupils were strongly present in all of the teacher interviews although their intensity and the ways in which teachers expressed these emotions varied considerably. Dialogue 1 illustrates the scale of negative emotions from the beginning of the teachers' careers.

\section{DIALOGUE 1}

Jenna Somehow students demand a lot from the teacher. Almost as if the teacher is their servant. (1)

Taina They have less manners than I had expected and I am amazed daily how the students can be so mean and ignorant about everything. (1)

Saila It irritates me when some students come to class and think they will get off easy as if nothing needs to be done and they are just not bothered. (2)

Tuuli To be honest, students are lazy. I thought it was bad in my previous job, but here it is unbelievable. It's a miracle if someone has done their homework. (2)

Jenna It is awful to teach passive groups. (1)

Taina I don't mind, if a student has poor skills, but when they really do nothing, when they make no effort whatsoever, that is the most irritating thing in class. (3)

Jenna I remember that autumn, when there were such lessons, and I was like "oh shoot, it's this again"! Those emotions were new to me. (1)

Anu They were strange emotions - that I could hate a student. (1)

Reetta If it happens, that you have to nag and tell the students off all the time - "be quiet, be quiet" - then it gets irritating and almost gives you a headache, when you are grumpy and things aren't working, then it's not nice, it won't work. (2)

Taina If my future career would be like this in secondary school... it cannot be the purpose of life, for me to be upset almost every day because I have to patrol and nag and get a headache because a student is winding me up. I thought: I cannot take this anymore, how can it be like this? (1) 
Tuuli Unfortunately here you often feel like: does this make any sense for either side? (3)

Anu Young kids downtown have started to irritate me more. I have perhaps become more cynical towards teens, not everyone, you cannot generalise, but towards some. (3)

Tuuli I could list a number of curse words here, but yeah, the upbringing should have been taken care of already, preferably at home. (3)

Linnea Sometimes I seriously think about how I'm going to be able to do this until I retire. (1)

As seen above, the negative emotions were at times strong, including anger and disappointment. These emotions were mostly related to students' lack of good behaviour and passiveness. The teachers were sometimes disappointed in the extra work: they felt they were not allowed to be foreign language teachers, as a significant amount of time and energy was consumed by classroom management. Moreover, frustration was often present in the secondary level since the teachers had to spend time 'parenting'. In the teachers' accounts, two kinds of reactions to this emotional load are visible. In some instances, negative emotions make teachers doubt their

ability to continue working as teachers, in other instances the teachers reject the responsibility they are given. Although these emotions appear to be exhausting, the presence of these emotions can also be considered as important signposts for teachers to reconsider their practices. By making teachers doubt the meaningfulness of their work, these negative emotions can be a stimulus for change in practices.

\section{Mixed emotions}

In the teacher interviews, the way in which the different teachers described emotions varied greatly. As Figure 1 illustrates, mixed emotions were especially present during the second year in the profession. Most of the sound bites in the second dialogue are from the second interview with a few sound bites from the third interview.

\section{DIALOGUE 2}


Tuuli Sometimes a lesson goes really well and you can feel satisfied a long time after, until you experience a poorer lesson. (2)

Jenna At times it is so wonderful to teach. When you have many nice lessons in a row, you feel great; it's lovely to be a teacher. Then you face a group of students with no motivation, and they behave terribly. You simply readjust and try to be stricter next time. The emotions vary from side to side. (3)

Tuuli Occasionally you feel furious, like 'help!', and other times you are so happy over a ridiculously small thing. (3)

Taina Luckily it's not only me whose mood swings from lesson to lesson. (2)

Anu There are two sides of the same coin; sometimes they give me so much strength so I can carry on. And from time to time I feel like I walk to the storeroom boiling with fury and would like to smack things around. Sometimes one person can drive me mad and other times cheer me up like never before. (2)

Saila The group I have been working with is mainly nice, but there is this one student, who I would like to throw to the wall every single time we meet. I cannot understand how a person comes in with an 'I couldn't care less' attitude. (2)

Anu You dare to show your positive emotions, but not the negative ones. (3)

Linnea But they know me. They know that I might lose my nerves sometimes and the next time I'll be in a good mood. They know how to deal with it. (2)

Taina They can tell by the look at my face whether I am in a good or bad mood and when I am going to snap. One day it's fun with them, and the next day it's something else. (2)

Reetta The students you know yourself, are nice, but I cannot claim that I am excited about every student. (2)

Anu I have learned to get on with it. After all, not everybody likes me, so I don't have to like everybody. (5)

Tuuli It's mainly that they're unable to be quiet, but it's not that big of a deal. (1)

Reetta But when you are with them in class, you just cope somehow, you always do. 
As seen in the dialogue, the emotions sometimes varied from lesson to lesson. Occasionally individual students would trigger the emotions and other times a whole group was behind the changing moods. Knowing the students was often the key for positive emotions, while unfamiliar students could generate irritation. Emotions of students were seen as varying too, affecting the teacher as well.

The mixed, varying emotions of teachers and students brought a level of uncertainty to the teachers' lives - one could not always predict what was going to happen and what the atmosphere in each lesson was going to be like. The expressions of varying emotions can also be understood in terms of reflective attempts to compensate the negative with the positive in the interview situation. Instead of being crushed by the negative emotions, the teachers found from their more positive emotions strength and perspective that helped them to cope with the negative ones.

\section{Positive emotions}

Positive emotions in relation to students were mentioned throughout the interviews over the years and some of the teachers talked more about the positive emotions in their latest interview compared to the earlier ones. These sound bites are from across the teachers' careers. Arranging them was straightforward, since many teachers had similar experiences of positive emotions and they complemented one another.

\section{DIALOGUE 3}

Jenna It is rewarding to notice that students liked something. And things they say can be rewarding. (1)

Linnea When both I and the students feel relaxed, that is most rewarding. (2)

Taina It is immensely rewarding to be yourself with students, be relaxed and do things calmly. It gives you so much. (2)

Reetta I think I can connect with the students rather well. (1)

Anu Some groups are almost like your own children, in a way that you are really close to them. (3) 
Jenna Students bring you satisfaction. To see them develop. Or just the joy and enthusiasm they have in their eyes. (5)

Saila When you see that your students are excited, even just a little, at least from time to time, it is important because that keeps your own enthusiasm going. (2)

Tuuli If everybody has been in a good mood and things run smoothly, that cheers you up. (1)

Reetta You feel better, when the students are happy about the stuff they have learned.

Tuuli In my opinion they give you a lot. (5)

Taina Mostly the students are really nice. In that sense, it is always nice to come to work and class. (5)

Anu I put them first. Surely colleagues are important, but students are even more important. I work with them, more than I work with teachers. (5)

Reetta They are quite important people, after all I would not have a job without them. And they are such a joy sometimes. (2)

Jenna They demand and affect your mood, but I feel like they are the reason for me being here. Partly they are so lovely and I think the challenging students are wonderful to work with too. (3)

Taina They are mainly good guys. (5)

Saila They are such. Such dear sweethearts. (5)

Often a relaxed atmosphere and easy-going interactions with students were satisfying for the teachers. The teacher-student relationships clearly mattered and when smooth, they were considered rewarding. These positively rewarding emotions were particularly highlighted in the first interviews. The sound bites from the later interviews also show a new variety of positive emotions evolving. Instead of regarding their work only from the perspective of the ease of smoothness of the teacher-pupil -relationship, the pupil perspective became more significant. At this point the students' enthusiasm and development brought about positive emotions for the teacher.

\section{Shifting emotions of FL teachers' work}




\section{Change in FL teachers' emotions}

As illustrated in Figure 1, the negative emotions decreased interview by interview. Not only was the number of the negative emotions higher in the first interviews, but also their intensity. The volume and nature of these emotions had surprised some of the teachers. The strong negative emotions teachers encounter in the beginning of their career indicate the difficulty with which teachers encounter the concrete experience of teaching (Bakhtin, 1993). The awkwardness of being considered responsible for other people, not only for 'idealized pupils' is reflected in the dialogue in the strong emotional reactions of the teachers. While the negative emotions decrease with time, at the same time the positive emotions are described more frequently and they also gain in intensity. These developments were frequently reflected by the teachers in the interviews. In dialogue 4 , the teachers comment on this change and ponder some of the reasons behind the changes. Some changes are taking place already in the second interview.

\section{DIALOGUE 4}

Saila At first I was like shut up, of course I did not say that, but now I perhaps chill a bit more, like go in one ear and out the other. (2)

Taina Compared to last year, I let stuff pass more easily. I'm not left worrying about things they say. (2)

Linnea As long as they pretty much behave and do not hassle about, I am satisfied. That has changed. It's easier to loosen up when you have been strict at first. (2)

Anu You know, the emotions have become milder, the negative ones. The positive emotions are sometimes rather strong, but these negative emotions, they are less and less present. Those emotions turn a lot milder, once you get to know the students. (5)

Linnea Sometimes I think it would be good, that teachers would know more about students, in order to be more sensitive. When something has happened at home and we don't know about it, those are awkward situations. (2)

Tuuli Actually I am somewhat interested in how the students are doing. (4)

Reetta And I might be a bit more interested in the students nowadays. (5) 
Linnea Perhaps I have gained a better understanding of their lives. (2)

Jenna You cannot do this job if you don't do it with your heart. I have noticed it many times this autumn after a challenging lesson. (3)

Taina In a way I miss comprehensive school: even though they are undisciplined, the lessons are filled with life and energy, which is good on the other hand. (3)

Reetta I mean if the language learning won't work with some of them is it really such a disaster, you don't have to get depressed over it. (5)

Anu I have become more relaxed regarding this issue. I have become more understanding. (5)

Tuuli What comes to behaviour issues and such, I just think that anything can happen and you deal with it one way or another. (5)

Jenna The biggest change for me has been putting things in perspective. You consider: what is the significance of this for the child or teen? So that it isn't just my professional ambition at stake. In this issue I have grown. (5)

Tuuli I don't take this job so seriously anymore, because well, I have a family now. (5)

Reetta I would start to think, that I had been a safe adult to some of them, something they had not had at home. I had not realized this before. (2)

In the teachers' reflections certain factors are highlighted. Most teachers thought that the positive change in their emotions coincided with their increasing experience as teachers. Situations that would have caused negative emotions earlier were now something familiar to them. Pupil behaviour did not surprise them anymore and having one's own family helped some of the teachers to get a wider perspective. The teachers tended to take their job less seriously and became more relaxed. The teachers also perceived these changes in relation to their increased understanding of their pupils' lives. Emotional experiences altered when the teachers learned to know their pupils better and their relationship also changed. This was often considered as the main factor for further changes in emotions. This change in the teachers' dialogical relationship with pupils, that is the way in which teacher-pupil relationships were re-framed is the focus of the next section. 


\section{Re-framing teacher-pupil relationships}

To better understand the shifting emotions of teacher experience it is important to ask what kind of relationships frame emotions. Dialogue 5 illustrates the ways in which relationships between teachers and pupils were re-framed across the different interviews.

\section{DIALOGUE 5}

Taina The students are guinea pigs at this stage. In a way they are tools for work. (3)

Tuuli My basic duty is to arrive in class, teach languages and that, in my opinion, is the stuff I'm here to do. (3)

Reetta Yes, you raise them to be a part of the society. I haven't thought about it much, I just work there. (1)

Tuuli What is important in teaching, well, maybe the co-operation with students. And second, that they like languages and it's fun to teach them. (5)

Linnea I try to notice students as individuals. Students are the main thing in this job. (5)

Reetta After having a child of my own, I'm like: this is just language learning. Since before, you had a narrower view, you just looked at the students and saw them as learners of the language. (5)

Anu A student might have some serious problems and that's why he/she isn't able to do homework. (5)

Jenna Even before I looked at students more comprehensively, not just from within my own subject. It was my mission, not to categorise students based on their performance in my class. I do it more and more now. (5)

Anu Well, sometimes I feel like teaching is beside the point. From time to time we just talk about stuff that puzzles the students. (5)

At first the pupils were perceived in the light of the understanding the teachers had formed about FL teachers work during their studies. In many cases this understanding highlighted FL teaching 
as a primarily cognitive process. The pupils were expected to concentrate on learning a language according to teacher instructions. The pupils, however, did not easily adjust to this role of an obedient language learner. The lived experience of teaching was significantly different from the teachers' original beliefs about or theoretical knowledge of FL teaching (Bakhtin, 1993). At this stage, the relationship was perceived to be between an eager FL teacher and unwilling pupils. The difficulties that emerge in this dialogue are reflected in the teachers' strong negative emotions.

Dialogue 5 illustrates, however, a clear change in this relationship over the nine-ten year period. As a result of learning to know their pupils, five of the teachers start to perceive themselves and their pupils in different ways. The relationship was no longer as much between a language teacher and a pupil, but between an educator and a child or a youth. The understanding of their role as an important adult, somebody who can make a difference was considered as a significant factor for the change they experienced. This fuller understanding of pupils' lives made the joys of their development more significant and changed the meaning of their immature behaviour. It was now understood in an educational context where the pupils are in need of guidance and not supposed to be perfect. Some mentioned an increased interest towards students which worked in the teachers' advantage, helping teachers to build closer relationships with their students.

\section{Discussion}

This article investigates the emotions of seven FL teachers - the emotions they experience, the way in which emotions change over time and the relationships that frame teacher emotion. The emotional experiences of FL teachers reported here complement the results of earlier research (Hagenauer, Hascher, \& Volet, 2015; Kanno \& Stuart, 2011; Zembylas, 2004) and add a longitudinal perspective. The dialogical approach applied in the analysis of the teacher interviews was sensitive to the personal nature of emotion (Newberry, 2014) as well the social nature of emotion (Campos et al., 2011; Nias, 1996; Zembylas, 2003). By identifying key moments in the teacher interviews the intrapersonal dialogues and shifting emotions of teachers came into view. By putting key moments from different teachers side-by-side to form a dialogue provided a broader view of teacher emotion. 
The negative emotions were particularly present in the early years of teaching and experiencing those emotions was exhausting for the teachers. This raises questions for foreign language teacher education as to whether emotions are sufficiently addressed in teacher education. If novice teachers are better prepared to face negative emotions, perhaps the first years in the profession would be less exhausting. It might also be useful for novice and experienced teachers to recognise negative emotions as signposts and important clues to further development. This research suggests that negative emotions can indicate that expectations and attitudes need to be reconsidered (see also Timoštšuk \& Ugaste, 2012; Golombek \& Johnson, 2004) that the quality of relationship between teacher and pupils requires attention or a new perspective needs to be sought. By recognising negative emotions as indicators of potential development, we hope that the lived experience of teachers would enrich pedagogical understanding rather than undermine pedagogical intentions and the emotional resources of teachers.

The findings concerning mixed emotions were similar to those in previous literature. $\mathrm{Xu}$ (2013) as well as Nyman and Ruohotie-Lyhty (2008) found teachers expressing mixed emotions towards students, whereas Cowie (2011) found emotions towards students to be mainly positive. The different contexts of the studies might account for these differences, with Cowie's (2011) study focusing on university level education. In the present study emotions were particularly ambivalent during the second interview and the teacher participants appeared more selective in their expressions of caring for students favouring the pupils they teach themselves. Recognizing emotions, however, can help individuals know themselves better and can support the understanding of emotions of others enriching the dialogical relationship between self and other.

Relationships with students can be caring and sources of joy (Cowie, 2011; O'Connor, 2008; Veldman et al., 2013; Xu, 2013) and the results from this study reiterate previous findings concerning positive emotions related to students. Teachers in this study found relaxed interactions with students empowering and on occasion the teacher descriptions of students were full of warmth and affection. Whereas negative emotions provide important information defects and potential development, positive emotions provide strength and perseverance. Studying positive and negative emotions further might increase understanding of teachers' job satisfaction (Fisher, 2000; Keller et al., 2014) and help to resolve the seeming 
contradiction between 'invisible' yet felt emotions - inevitable within the personal-social context of education.

Perhaps the most significant research question concerned change and whether emotion in relation to students altered as the teachers' careers progressed. Clearly, there were changes: the negative emotions decreased and became milder while the positive emotions increased. Reasons for the changes varied. Teachers described these changes as partly due to their further experience of teaching and ability to put things into perspective. Over time, teachers learnt to take negative incidents less seriously, importantly, however, the analysis also showed that most of the participants also perceived their relationship with the pupils differently by the fifth interview. Initially the teachers saw the pupils as language learners. It was only later that the teachers began to recognise pupils as children, teens and individuals. This realisation evidently affected the teachers' emotions as they shifted in a warmer direction indicating how inseparably emotions are related to the relationship with the world (Sullivan, 2012; Ruohotie-Lyhty \& Moate, 2015).

In this research, for foreign language teachers to experience more positive emotions towards their pupils, they first had to accept their educational responsibility as teachers and to recognise pupils as more than language learners. This kind of emotional change necessitates readiness to reconsider original beliefs about the responsibilities of language teachers so that the teachers could respond better to their pupils' needs. As the teachers' emotions changed, they appeared to be able to go beyond their initial assumptions, to go beyond the abstractly ideal language learners possibly envisaged during teacher education and to instead meet and learn to work with their actual pupils.

This gap between the anticipated and the actual is an area that should be further addressed in foreign language teacher education. Subject knowledge is crucial for teachers, but the work of language teachers often includes multiple aspects that go beyond subject expertise, such as classroom management, supporting pupils in their difficult life situations and working to create better learning communities and groups. Responsibilities related to upbringing are not unusual in secondary school; therefore, this point of view should be taken into account in foreign language teacher education. As one of the teachers said, 'Situations occur where you have to be something other than a language teacher'. If student teachers can gain a better understanding of the complex emotional relationships teachers have with their pupils and their responsibility as 
educators during the teacher education, this would hopefully help them as newly qualified teachers to better prepare for the everyday experiences of teaching foreign languages.

The present study has certain limitations. Firstly, this study charted the emotions that FL teachers have in relation to their pupils in different phases of their career and provided an overview of some of the ways in which emotions can contribute to teacher development. Further research is needed to understand more deeply the relationships between individual teacher development and teachers' emotions. Secondly, the study has relied on teacher memories and emotional incidents that have been salient enough for them to be mentioned during interviews. The results are not, therefore, generalisable to reflect the everyday emotional lives of teachers which is something that journals could reveal more in this respect. A third limitation concerns the monomodal analysis that limited the focus to the participants' linguistic utterances to construct a big picture of their emotions. A more multimodal analysis including gestures, head movement, posture and so on would permit to create a more holistic approach. (Imai, 2010, p. 289.) Nevertheless, this study offers a new longitudinal perspective on foreign language teachers' emotion in relation to students.

To conclude, a major source of teachers' emotion is the relationship with students. It is no surprise, considering that emotions arise in social situations (Campos et al., 2011; Fischer \& Van Kleef, 2010; Keltner et al., 2014). This study has given voice to seven foreign language

teachers from different school levels. The longitudinal aspect has made it possible to shed light on the different emotions teachers and how over time teachers learn to cope with the emotional dimension of teaching. The extent of the emotional rollercoaster present in this study suggests, however, that this is an area that requires more attention in pre-service as well as in-service teacher education.

\section{References}

Aragão, R. (2011). Beliefs and emotions in foreign language learning. System, 39(3), 302-313. Arnold, J. (Ed.) (1999). Affect in language learning. Cambridge: Cambridge University Press. Bakhtin, M. M. (1990). Art and answerability: Early philosophical essays. Austin, TX: University of Texas Press. 
Bakhtin, M. M. (1993). Toward a Philosophy of the Act. Austin, TX: University of Texas Press.

Benesch, S. (2012). Considering emotions in critical English language teaching: Theories and praxis. Abington: Routledge.

Campos, J. J., Walle, E. A., Dahl, A., \& Main, A. (2011). Reconceptualizing emotion regulation. Emotion Review, 3(1), 26-35.

Carter, K., \& Doyle, W. (1996). Personal narrative and life history in learning to teach. In J. Sikula (Ed.), Handbook of research on teacher education (pp. 120-142). New York: Macmillan.

Cowie, N. (2011). Emotions that experienced English as a foreign language (EFL) teachers feel about their students, their colleagues and their work. Teaching and Teacher Education, 27(1), 235-242.

Day, C., \& Gu, Q. (2010). The new lives of teachers. Abington: Routledge.

Day, C., Kington, A., Stobart, G., \& Sammons, P. (2006). The personal and professional selves of teachers: Stable and unstable identities. British Educational Research Journal, 32(4), $601-616$.

Fischer, A. H., \& Van Kleef, G. A. (2010). Where have all the people gone? A plea for including social interaction in emotion research. Emotion Review, 2(3), 208-211.

Fisher, C. D. (2000). Mood and emotion while working: Missing pieces of job satisfaction? Journal of Organizational Behavior, 21, 185-202.

FNBE (2014). National Core Curriculum for Basic Education. Helsinki: Finnish National Board of Education, in Finnish.

Galman, S. (2009). Doth the lady protest too much? Pre-service teachers and the experience of dissonance as a catalyst for development. Teaching and Teacher Education, 25, 468-481.

Gao, X. (2008). Teachers' professional vulnerability and cultural tradition: A Chinese paradox. Teaching and Teacher Education, 24, 154-165.

Golby, M. (1996). Teachers' emotions: An illustrated discussion. Cambridge Journal of Education, 26(3), 423-435.

Golombek, P. \& Johnson, K. E. (2004). Narrative inquiry as a mediational space: Examining emotional and cognitive dissonance in second language teachers' development. Teachers and Teaching: Theory and Practice, 10(3), 307-27.

Hagenauer, G., Hascher, T., \& Volet, S. E. (2015). Teacher emotions in the classroom: 
Associations with students' engagement, classroom discipline and the interpersonal teacher-student relationship. European Journal of Psychology of Education, 30(4), 385-403. Hargreaves. A. (1998). The emotional practice of teaching. Teaching and Teacher Education, 14, 836-854.

Hargreaves, A. (2000). Mixed emotions: teachers' perceptions of their interactions with students. Teaching and Teacher Education, 16, 811-826.

Hargreaves, A. (2001). Emotional geographies of teaching. The Teachers College Record, 103(6), 1056-1080.

Hicks, D. (1996). Learning as a prosaic act. Mind, Culture, and Activity, 3(2), 102-118.

Imai, Y. (2010). Emotions in SLA: New insights from collaborative learning for an EFL classroom. The Modern Language Journal, 94(2), 278-292.

Kanno, Y., \& Stuart, C. (2011). Learning to be a second language teacher: Identities-in-practice. The Modern Language Journal, 94, 236-252.

Kauppinen, E. (2010). Opettajien tunnenarratiivit ja niiden rakenneanalyysi. Musiikin ja matematiikan aineenopettajien opettajuus ja elämänkulku [A structural analysis of teachers' emotion narratives. Music and mathematics teachers' professional identities and life stories]. Tampere: Tampere University Press.

Keller, M. M., Frenzel, A.C., Goetz, T., Pekrun, R., \& Hensley, L. (2014). Exploring teacher emotions. A literature review and an experience sampling study. In P.W. Richardson, S.A. Karabenick \& H.M.G. Watt (Eds.), Teacher motivation. Theory and practice (pp. 69-82). New York: Routledge.

Keltner, D., Oatley, K., \& Jenkins, J. M. (2014). Understanding emotions. Hoboken, N.J.: Wiley Global Education.

Kumazawa, M. (2013). Gaps too large: Four novice EFL teachers' self-concept and motivation. Teaching and Teacher Education, 33, 45-55.

Kvale, S., \& Brinkmann, S. (2009). InterViews: Learning the craft of qualitative research interviewing. Thousand Oaks: Sage.

Liljestrom, A., Roulston, K., \& deMarrais, K. (2007). "There is no place for feeling like this in the workplace”: Women teachers' anger in the school settings. In P.A. Schutz \& R. Pekrun (Eds.), Emotion in education (pp. 275-291). Amsterdam: Elsevier. 
Madill, A., \& Sullivan, P. (2010). Medical training as adventure-wonder and adventure-ordeal: A dialogical analysis of affect-laden pedagogy. Social Science \& Medicine, 71(12), 21952203.

Neville, B. (2013). The enchanted loom. In Riley, P., Gallant, A., Newberry, M. (Eds.), Emotion and school: Understanding how the hidden curriculum influences relationships, leadership, teaching, and learning. Advances in research on teaching (vol. 18, pp. 3-23). UK: Bingley.

Newberry, M. (2013). The demand of multiplicity in the classroom: emotion regulation and cognitive load. In Riley, P., Gallant, A., Newberry, M. (Eds.), Emotion and school: Understanding how the hidden curriculum influences relationships, leadership, teaching, and learning. Advances in research on teaching (vol. 18, pp. 25-48). UK: Bingley.

Nias, J. (1996). Thinking about feeling: The emotions in teaching. Cambridge Journal of Education, 26, 293-306.

Nyman, T. \& Ruohotie-Lyhty, M. (2008). Tunteet pelissä: kielenopettajan tunnetiloja uran alkuvaiheessa [Emotion at stake: language teachers' emotional states at the beginning of their career]. In R. Jaatinen, V. Kohonen, \& P. Moilanen (Eds.), Kielikasvatus, opettajuus ja kulttuurienvälinen toimijuus [Language education, teaching and intercultural agency] (pp. 203-221). Helsinki: Okka.

O'Connor, K. E. (2008). "You choose to care": Teachers, emotions and professional identity. Teaching and Teacher Education, 24(1), 117-126.

Polkingthorne, D. E. (1996). Narrative knowing and the study of lives. In J. Birren (Ed.), Aging and biography: Explorations in adult development (pp. 77-99). New York: Springer.

Rodgers, C. R., \& Raider-Roth, M. B. (2006). Presence in teaching. Teachers and Teaching: Theory and Practice, 12(3), 265-287.

Roth, W. M. (2002). Being and becoming in the classroom. Westport, CT: Ablex Publishing.

Ruohotie-Lyhty, M. (2009). Newly qualified language teachers' agency and professional development during the first years at work. In R. Kantelinen, \& P. Pollari (Eds.), Language Education and Lifelong Learning (pp. 279-303). Joensuu: University of Eastern Finland, Philosophical Faculty School of Applied Educational Science and Teacher Education.

Ruohotie-Lyhty, M. (2011). Opettajuuden alkutaival: Vastavalmistuneen vieraan kielen opettajan toimijuus ja ammatillinen kehittyminen [First steps on the path of teacherhood: Newly 
qualified foreign language teachers' agency and professional development]. Jyväskylä: University of Jyväskylä.

Ruohotie-Lyhty, M. (2013). Struggling for a professional identity: Two newly qualified language teachers' identity narratives during the first years at work. Teaching and Teacher Education, 30(1), 120-129.

Ruohotie-Lyhty, M. (2016). Stories of Change and Continuity: Understanding the Development of the Identities of Foreign Language Teachers. In P. Kalaja, A. Barcelos, M. Aro, \& M. Ruohotie-Lyhty, Beliefs, agency and identity in foreign language learning and teaching (pp. 172-201). Basingstoke: Palgrave Macmillan.

Ruohotie-Lyhty, M., \& Moate, J. (2015). Proactive and reactive dimensions of life-course agency: mapping student teachers' language learning experiences. Language and Education, 29(1), 46-61.

Sabar, N. (2004). From heaven to reality through crisis: Novice teachers as migrants. Teaching and Teacher Education, 20(2), 145-161.

Shuman, V., \& Scherer, K. (2014). Concepts and structures of emotions. In R. Pekrun \& L. Linnenbrink-Garcia (Eds.), International handbook of emotions in education (pp. 13-35). New York, NY: Taylor \& Francis.

Schutz, P.A. (2014). Inquiry on teachers' emotion. Educational Psychologist, 49(1), 1-12.

Sullivan, P. (2007). Examining the self-other dialogue through 'spirit'and 'soul'. Culture \& Psychology, 13(1), 105-128.

Sullivan, P. (2012). Qualitative data analysis using a dialogical approach. London: Sage.

Sullivan, P., \& McCarthy, J. (2004). Toward a dialogical perspective on agency. Journal for the Theory of Social Behaviour, 34(3), 291-309.

Sullivan, P., \& McCarthy, J. (2005). A dialogical approach to experience-based inquiry. Theory \& Psychology, 15(5), 621-638.

Sutton, R.E., \& Wheatley, K.F. (2003). Teachers' emotions and teaching: A review of the literature and directions for future research. Educational Psychology Review, 15(4), 327 358.

Timoštšuk, I., \& Ugaste, A. (2012). The role of emotions in student teachers' professional identity. European Journal of Techer Education 35(4), 421-433. 
Troman, G., Jeffrey, B., \& Raggi, A. (2007). Creativity and performativity policies in primary school cultures. Journal of Educational Policy, 22, 549-572.

van Manen, M. (1991). The Tact of Teaching. Albany, N.Y.: State University of New York Press.

Veldman, I., van Tartwijk, J., Brekelmans, M., \& Wubbels, T. (2013). Job satisfaction and teacher-student relationships across the teaching career: Four case studies. Teaching and Teacher Education, 32, 55-65.

Wharton, A. S. (2009). The sociology of emotional labor. Annual Review of Sociology, 35, 147165.

Xu, Y. (2013). Language teacher emotion in relationships: A multiple case study. In X. Zhu, \& K. M. Zeichner, (Eds.) Preparing teachers for the 21st century (pp. 371-393). New York: Springer.

Zembylas, M. (2003). Emotions and teacher identity: A poststructural perspective. Teachers and Teaching: theory and practice, 9(3), 213-238.

Zembylas, M. (2004). The emotional characteristics of teaching: an ethnographic study of one teacher. Teaching and Teacher Education, 20(2), 185-201.

Zembylas, M. (2007). Theory and methodology in researching emotions in education. International Journal of Research \& Method in Education, 30(1), 57-72.

Zhang, Q., \& Zhu, W. (2008). Exploring emotion, in teaching: Emotional labor, burnout, and satisfaction in Chinese higher education. Communication Education, 57(1), 105-122. 


\section{Appendix}

Interpersonal dialogue from Anu

They were strange emotions, that I could hate a student. Thinking: oh no, not that kid again, I hate him, I hate him, I can't stand him. He is irritating. (1)

On the other hand, those emotions turn a lot milder, once you get to know the students. (1)

Students, students are probably the best thing. (2)

There are two sides of the same coin, sometimes they give me so much strength, so I can carry on. And from time to time I feel that I go to the storeroom boiling and would like to smack things around. Sometimes one person can drive me mad and other times cheer me up like never before. (2)

Some groups are almost like your own children, in a way that you are really close to them. Another group is like a work in progress, so to say. They are my job. (3)

You dare to show your positive emotions, but not the negative ones. (3)

Young kids downtown have started to irritate me more. I have perhaps become more cynical towards them, not everyone, you cannot generalise, but towards some. (3)

The ninth grade left and I sighed with relief; we're getting rid of the bastards. It was a terrible group. All of it. I made such an effort for them and many were transferred to a smaller group and special education and the group just had multiple problems. (5)

A student might have some serious problems and that's why he/she isn't able to do homework. (5)

I have become more relaxed regarding this issue. I have become more understanding. (5)

You know, the emotions have become milder, the negative ones. The positive emotions are sometimes rather strong, that I like sometimes so much. It makes me cry beforehand to think about one group leaving. But these negative emotions, they are less and less present. But, usually I'm annoyed by students I don't teach. (5)

But then I have learned to get on with it. After all, not everybody likes me, so I don't have to like everybody. (5)

Students. I put them first. Surely colleagues are important, but students are even more important. I work with them, more than I work with teachers. (5) 
Well, sometimes I feel like teaching is beside the point. We just sometimes talk about stuff that puzzles the teens. (5) 